\title{
Focusing the Inquiry: Specificity in the Merger Guidelines and Elsewhere
}

\author{
David A. Clanton $\dagger$
}

In June of 1982, the Department of Justice and the Federal Trade Commission issued revised merger guidelines.' The drafters had to choose between very general standards, that permit all relevant factors to be considered, and more specific bright line standards that, while easier to apply, might omit important factors. This choice is not unique to merger law. The same tradeoffs are also made in many other areas of antitrust in deciding whether to adopt the rule of reason or rules of per se illegality, or any of the gradations in between. ${ }^{2}$

A common reaction to the new Guidelines is that they err on the side of considering too many factors. ${ }^{3}$ They are seen as too vague and general, reducing to some extent the certaimty and predictability of the old merger law. ${ }^{4}$ There is usually an honest recognition that the old law was occasionally too extreme in the other direction, and that some reforn was needed to correct a situation where, in Justice Stewart's words, the only rule was that "the Government always wins." The

$\dagger$ Commissioner and former Acting Chairman of the Federal Trade Commission. The author is one of the drafters of the Statement of Federal Trade Commission Concerning Horizontal Mergers. The views expressed are the author's own, and should not be taken as official FTC positions. The author gratefully acknowledges the assistance of Richard Craswell and Susan G. Braden in the preparation of this Article.

1. U.S. Dep't of Justice, Merger Guidelines, 47 Fed. Reg. 28,493 (1982), reprinted in 71 CALIF. L. REv. 649 (1983) [hereinafter cited without cross-reference as Guidelines]; FTC, Statement Concerning Horizontal Mergers, reprinted in TRADE REg. REP. (CCH) No. 546, at 71 (June 16, 1982) (special supplement to 2 TRADE REg. REP. (CCH) $\mid 4225$ (Aug. 9, 1982)) [hereinafter cited as FTC Statement].

2. See, e.g., Clanton, Report from the Federal Trade Commission, 50 ANTITRust L.J. 145, $146-48$ (1981).

3. See, e.g., Harris \& Jorde, Market Definition in the Merger Guidelines: Implications for Antitrust Enforcement, 71 CALIF. L. REv. 464, 484 (1983); Turner, Observations on the New Guidelines and the 1968 Guidelines, 51 ANTrTRust L.J. 307 (1982); Sims \& Blumenthal, New Merger Guidelines Provide No Real Surprises, Legal Times (Washington), June 21, 1982, at 17, col. 1; Spivack, New Merger Guidelines Are Substantially Different, Legal Times (Washington), Aug. 2, 1982, at 38, col. 1 .

4. See, e.g., Turner, supra note 3.

5. United States v. Von's Grocery Co., 384 U.S. 270, 301 (1966) (Stewart, J., dissenting). While Justice Stewart's statement was true at the time, i.e., the government had won every merger case previously decided by the Warren Court, it became much less trne in the 1970's. See, e.g., United States v. General Dynamics Corp., 415 U.S. 486, 496-98 (1974). 
recognition of the need for reform, however, is often combined with a sort of nostalgia for those good old days when, if the rule was overly strict, it at least appeared to be easy to apply.

This Article challenges this criticism of the revised Guidelines. To some extent, this nostalgic view not only misperceives the contribution of the Guidelines, it also exaggerates the predictability of the old merger law. ${ }^{6}$ Furthermore, in some ways the Guidelines may serve to make merger law more definite and predictable, by specifying more clearly just what factors will be used (and under what circumstances) to assess a merger's competitive effects. In fact, this Article will argue that the antitrust agencies should consider taking a similar approach (though not necessarily involving formal guidelines) to deal with other equally difficult areas of antitrust law.

Thus, the purpose of this Article is to examine in more detail the nature of the Guidelines' tradeoff between predictability and analytic completeness. Part I of this Article briefly examines the pre-Guidelines law dealing with horizontal mergers, ${ }^{7}$ both as it was announced by the Supreme Court and as it was actually applied by the lower courts. Part II argues that the Guidelines narrow the range of factors that will be considered, and help focus the inquiry by making the relative importance of these factors more easily understood. Finally, Part III discusses some possible ways in which an approach similar to that in the Guidelines could bring greater predictability to other areas of antitrust.

\section{I}

The Pre-Guidelines Case Law (1962-1982)

Most discussions of horizontal merger law begm with the Supreme Court's decisions in Brown Shoe Co. v. United States ${ }^{8}$ and United States v. Philadelphia National Bank. ${ }^{9}$ In Brown Shoe, the Court noted that Congress liad consciously avoided "exclusively mathematical tests" in drafting section 7 of the Clayton Act. ${ }^{10}$ Instead, the Court held that a broad range of factors ought to be considered in assessimg any particular merger. ${ }^{11}$ In language strikingly similar to the new Guidelines, the

6. Ragowsky, An Analysis of the Application of the Justice Department's Merger Guidelines (Mar. 1982) (FTC staff working draft).

7. While vertical and conglomerate mergers are also addressed by the Guidelines, this Article discusses only horizontal mergers.

8. 370 U.S. 294 (1962).

9. 374 U.S. 321 (1963).

10. 370 U.S. at 321 n.36.

11.

Congress indicated plainly that a merger had to be functionally viewed, in the context of its particular industry. That is, whether the consolidation was to take place in an industry that was fragmented rather than concentrated, that had seen a recent trend toward domination by a few leaders or had remamed fairly consistent in its distribution of mar- 
Court recognized that market share statistics would be important in this inquiry, but went on to say that "only a further examination of the particular market-its structure, history, and probable future-can provide the appropriate setting for judging the probable anticompetitive effect."12

A year later, however, the Court seemed to retreat from this requirement of a broad inquiry. In Philadelphia National Bank, the Court noted that the likely effect of a merger was "not the kind of question which is susceptible of a ready and precise answer," and that the relevant economic data were usually both "complex and elusive."13 Stressing the need for clear rules so that businessmen would be able to determine the legal consequences of a planned merger, the Court adopted a rule that placed a heavy reliance on market share figures. ${ }^{14}$ This emphasis on market share figures continued in succeeding merger decisions of the Warren Court. ${ }^{15}$

\section{A. Market Definition}

It would be a mistake, however, to view these decisions as representing a pristine era of clear rules for courts and certainty for executives. For one thing, market shares only became relevant once the market had been defined, and the Court's standard of market definition remained as elusive as ever. Without any convenient numerical measure of the extent of a product or geographic market, the Court in the Warren Era could not aumounce any bright line tests for that stage of the inquiry, and had to rely instead on a bare listing of the relevant factors that would be considered. ${ }^{16}$ Although market definition re-

ket shares among the participating companies, that had experienced easy access to markets by suppliers and easy access to supphers by buyers or had witnessed foreclosure of busimess, that had witnessed the ready entry of new competition or the erection of barriers to prospective entrants, all were aspects, varying in importance with the merger under consideration, which would properly be taken into account.

Id. at 321-22 (footnotes omitted).

12. Id. at 322 n.38.

13. 374 U.S. at 362 .

14.

Specifically, we think that a merger which produces a firm controlling an undue percentage share of the relevant market, and results in a significant increase in the concentration of firms in that market, is so inherently likely to lessen competition substantially that it inust be enjoined in the absence of evidence clearly showing that the merger is not likely to liave such anticompetitive effects.

Id. at 363 .

15. See, e.g., United States v. Aluminum Co. of Am. (Rome Cable), 377 U.S. 271, 278-81 (1964); United States v. Von's Grocery Co., 384 U.S. 270, $275-78$ (1966); United States v. Pabst Brewing Co., 384 U.S. 546, 552-53 (1966).

16. See Brown Shoe Co. v. United States, 370 U.S. 294, 325 (1962). See also United States v. E.1. du Pont de Neinours \& Co. (Cellophane), 351 U.S. 377, 394-95 (1956); United States v. Aluminum Co. of Am. (Rome Cable), 377 U.S. 271, 278-81 (1964); United States v. Continental Can Co., 378 U.S. 441,458 (1964). 
mains, of course, a difficult issue under the new Guidelines, it should be emphasized that this problem was also present under the old Guidelines.

In fact, one unintentional result of decisions like Philadelphia $\mathrm{Na}$ tional Bank was that much of the effort and controversy that would otherwise have been devoted to an assessment of the merger's competitive effects was imstead channeled into debates about the proper market definition. Defendants' lawyers could always find arguments for a broader market that gave the merging firms small market shares; similarly, plaintiffs' lawyers could always argue for a narrower market. While this undoubtedly provided continued employment for a number of lawyers, it also undid any certainty produced by a bright line test because the test could not be applied until the relevant market had been defined. ${ }^{17}$

\section{B. Market Shares and Other Factors}

Even if we restrict our attention to Warren Era cases where the market has already been defined, it would still be a mistake to assume that market shares were the only factors courts looked to in determining the legality of mergers. Although Philadelphia National Bank seemed to signal a move im that direction, the language of Brown Shoe was still available for any court that wanted to conduct a broader imquiry-and many of them did. The noninarket share factors relied on most frequently in the early cases were those that increased the likelihood of anticompetitive effects. For example, only a year after Philadelphia National Bank, the Supreme Court in United States $v$. Aluminum Co. of America (Rome Cable) ${ }^{18}$ emphasized that the acquired firm had a reputation as an innovative and aggressive competitor, and that the merger sliould therefore be prohibited in spite of the firm's small market share. ${ }^{19}$ Similarly, in United States $v$. Von's Grocery Co. ${ }^{20}$ the Court justified its ruling agamst a merger involving very small market shares at least in part by pointing to the market's trend toward increasing concentration.

17. Note that it is also somewhat misleading to speak of a standard based solely on market shares as a "bright line test," as the courts have never clearly established the level of market shares that would make a merger illegal.

Another source of uncertainty during the Warren Era, which this Article will only briefly mention, involved mergers that were not purely horizontal. In a horizontal merger case, even small market shares in the area of horizontal overlap would not necessarily save the merger if one of the merging firms were a potential competitor of the other, or if there were a vertical relationship between the two firms. As very few mergers involved firms in totally unrelated lines of business, there was usually at least the possibility of a potential competition argument.

18. 377 U.S. 271 (1964).

19. Id. at 281.

20. 384 U.S. $270,277-78$ (1966). 
By 1968 (the year of the first Justice Department Guidelines), however, courts were also looking at nonmarket share factors that reduced the likelihood of anticompetitive effects. United States v. Tidewater Marine Service ${ }^{21}$ is probably the clearest example of a court examining such factors. In Tidewater Marine, the court allowed a merger even though the merged firm had an estimated $31 \%$ of the relevant market. Instead of relying solely on market share data, the court looked to the fact that entry barriers were virtually nonexistent, that there had been frequent entry and exit, and that the firms im the market were selling their services to large customers (the oil coinpames) that could easily integrate backwards. ${ }^{22}$

That courts were looking at "Other Factors" even in the 1960's should not be surprising. Market shares are, after all, only a crude ineasure of market power. ${ }^{23}$ The merger of two firms each with an $8 \%$ share may unean nothing, a little, or a great deal, depending on the characteristics of the market. Thus, given the crudeness of market share ineasures and the amount at stake im most merger litigation, it was inevitable that litigants would introduce as much other evidence as they could to support their position. In short, while the 1968 Justice Department Guidelines liad attempted to build an analytic framework based lieavily on market share data, ${ }^{24}$ other factors continued to be introduced by litigants and considered by courts.

Consequently, the Supreine Court's decision in United States $v$. General Dynamics Corp. ${ }^{25}$ was not as sharp a break with existing practices as might appear. In General Dynamics, the Court allowed the defendant to rebut a prima facie case built primarily on market share data by slowing that one of the inerging companies liad exhausted its uncommitted inineral reserves and was therefore mucl less of a com-

21. 284 F. Supp. 324 (E.D. La. 1968).

22. Id. at 338-40. See also, e.g., United States v. First Nat'l Bank, 311 F. Supp. 374,378 (M.D. Pa. 1970) (considering barriers to entry and trends toward concentration); Lunkenheimer Co. v. Condec Corp., 268 F. Supp. 667, $671-72$ (S.D.N.Y. 1967) (considering low entry barriers and the acquiring firm's reputation as an aggressive price cutter); United States v. Gimbel Bros., 202 F. Supp. 779, 780 (E.D. Wis. 1962) (considering the history of frequent entry, the heterogeneity of products in the relevant market, and the weakened financial condition of the acquired firm).

23. For sone recent discussions of this issue, see Fisher, Diagnosing Monopoly, Q. REv. Econ. \& Bus., Sunimer 1979, at 7, 17-18; Landes \& Posner, Market Power in Antitrust Cases, 94 HARV. L. Rev. 937, 947-52 (1981); Schmalensee, On the Use of Economic Models in Antitrust: The Realenion Case, 127 U. PA. L. Rev. 994, 1004-16 (1979).

24. The only nonmarket share factors mentioned in the 1968 Guidelines (other than a trend toward increasing market shares, and the failing company defense) were any special assets or other unique competitive factors represented by the acquired firm, and any differences between the two firms' products that might make the overlap less than perfectly horizontal. U.S. Dep't of Justice, Merger Guidelines-1968, para. 8 (May 20, 1968), reprinted in 2 TRADE REG. REP. (CCF) I. 4510, at 6884 (Aug. 9, 1982) [heremafter cited as 1968 Guidelines].

25. 415 U.S. 486 (1974). 
petitive force than its then-current market share would suggest. ${ }^{26}$ While this result might have been limited to the special facts of that case (i.e., a mining company with depleted reserves), the Court seemed to be making a more general statement. Quotimg the Brown Shoe opmion, the Court announced that market share data, while of great significance, was not a conclusive indicator of a merger's likely competitive effects. ${ }^{27}$ The Court therefore approved the District Court's broader inquiry into the "structure, history, and probable future" of the market in question. ${ }^{28}$

As a result, in recent years the lower courts have been even more uninhibited in considering other factors besides market shares. Other factors the courts have considered in their analysis of horizontal mergers include: barriers to entry, ${ }^{29}$ the history of successful or unsuccessful entry in the past, ${ }^{30}$ the trend toward increasing or decreasing concentration, ${ }^{31}$ the heterogeneity of the product, ${ }^{32}$ the size and sophistication of the industry's customers, ${ }^{33}$ the history of industry pricing behavior ${ }^{34}$ and profitability, ${ }^{35}$ the presence or absence of larger competitors, ${ }^{36}$ the presence of excess or insufficient capacity (in relation either to present or projected future demand), ${ }^{37}$ the rapidity of technological change in

26. Id. at 502-04.

27. Id. at 498 .

28. Id.

29. E.g., Kaiser Aluminum \& Chem. Corp. v. FTC, 652 F.2d 1324, 1341 (7th Cir. 1981); United States v. Consolidated Foods Corp., 455 F. Supp. 108, 138 (E.D. Pa. 1978); United States v. Blue Bell, Inc., 395 F. Supp. 538, 549 (M.D. Tenn. 1975).

30. E.g., United States v. International Harvester Co., 564 F.2d 769, 778 (7th Cir. 1977); Whittaker Corp. v. Edgar, 535 F. Supp. 933, 949-50 (N.D. Ill. 1982); United States v. M.P.M., Inc., 397 F. Supp. 78, 92 (D. Colo. 1975).

31. E.g., Kaiser, 652 F.2d at 1341; FTC v. National Tea Co., 603 F.2d 694, 701 (8th Cir. 1979); Crane Co. v. Harsco Corp., 509 F. Supp. 115, 125 (D. Del. 1981).

32. Strol Brewery Co. v. Malmgren, 1982-1 Trade Cas. (CCH) I] 64,670, at 73,644 (W.D. Wis. 1982).

33. FTC v. Great Lakes Chem. Corp., 528 F. Supp. 84, 94-96 (N.D. Ill. 1981).

34. E.g., Kaiser, 652 F.2d at 1341; Great Lakes Chem. Corp., 528 F. Supp. at 93; Weeks Dredging \& Contracting v. American Dredging Co., 1978-1 Trade Cas. (CCH) 162,010 at 74,320 (E.D. Pa. 1978).

35. United States v. Crowell, Collier \& Macmillan, Inc., 361 F. Supp. 983, 994-95 (S.D.N.Y. 1973).

36. Compare Kaiser, 652 F.2d at 1341 (dictum) and Consolidated Foods Corp., 455 F. Supp. at 138 (presence of a larger competitor a reason for viewing the unerger more leniently, on the ground that the merged firm would be a more effective competitor with the industry leader) with United States v. Tracinda Inv. Corp., 477 F. Supp. 1093, 1108 (C.D. Cal. 1979) (absence of a larger competitor cited as a reason for viewing the merger more lemently, on the ground that an industry without an obvious price leader is less likely to exhibit supracoinpetitive pricing).

37. Compare United States v. Hughes Tool Co., 415 F. Supp. 637, 643-44 (C.D. Cal. 1976) (demand growing in excess of capacity a factor making merger more acceptable, in a potential competition analysis, as the growth should encourage new entry and make collusion less likely) with Grumman Corp. v. LTV Corp., 665 F.2d 10, 15 (2d Cir. 1981) (growing demand made merger less acceptable, by increasing the importance of preserving sinall independent competitors) 
the industry, ${ }^{38}$ the financial health of the acquired firm, ${ }^{39}$ the postacquisition independence of the acquired firm, ${ }^{40}$ and any other factors that might bear on the likelihood of postmerger collusion or supracompetitive pricing. ${ }^{41}$

Obviously, not every case has engaged in so broad an inquiry. Some have even deliberately narrowed their inquiry, resisting the trend to look at a vast array of factors other than market shares. ${ }^{42}$ However, this diversity of views among the lower courts simply remforces the thesis of this Article: pre-Guidelines case law was not as clear and predictable as soine have argued.

\section{II}

\section{THE IMPACT OF THE GUIDELINES}

It is against this background of diverse views and factors that the contribution of the revised Guidelines must be assessed. To be sure, the Guidelines do not eliminate all uncertainty about the legal status of any particular merger. They attempt, however, to organize an analytical framework to keep the inquiry within reasonable bounds. Specifically, the Guidelines attempt to focus the imquiry in three important ways. First, they limit the circumstances in which factors other than market share will be considered. Second, by specifying the economic model to be used, the Guidelines better define the relative importance of each of those other factors. Finally, in some cases the Guidelines also limit the inquiry by specifymg certam factors that will not be considered. Each of these will be discussed in turn.

\section{A. When "Other Factors" Are Relevant}

The most obvious simplifying measure taken by the Guidelimes is that they specify thresholds of concentration above or below which fac-

and Weeks Dredging, 1978-1 Trade Cas. (CCH) at 74,324-25 (declining demand a factor making merger more acceptable, as it provided an "alternate explanation" for the trend toward a smaller number of firms in the industry).

38. Great Lakes Chem. Corp., 528 F. Supp. at 90-91.

39. E.g., National Tea Co., 603 F.2d at 701; International Harvester, 564 F.2d at 778; M.P.M., 397 F. Supp. at 95-103. 138.

40. E.g., International Harvester, 564 F.2d at 778; Consolidated Foods Corp., 455 F. Supp. at

41. E.g., Weeks Dredging, 1978-1 Trade Cas. (CCH) at 73,321 (jobs awarded through sealed bid auctions); Great Lakes Chem. Corp., 528 F. Supp. at 95 (customers of the industry favored the acquisition).

42. See, e.g., United States v. Healthco, Inc., 387 F. Supp. 258 (S.D.N.Y. 1975) (refusing to consider speculative predictions about future changes in market structure and entry conditions), aff'd mem, 535 F.2d 1243 (2d Cir. 1975); Elco Corp. v. Microdot, Inc., 360 F. Supp. 741, 751-52 (D. Del. 1973) (refusing to consider a market's trend toward decreasimg concentration and low barriers to entry, or the alleged need of the merging firms to compete inore effectively with larger competitors). 
tors other than market share take on less importance. ${ }^{43}$ For example, the Guidelines indicate that, whatever the significance of barriers to entry and other factors, no challenge is hikely to be brought in markets with a Herfindahl-Hirschman Index (HHI) below 1000.44 At the other end of the scale, the Guidelines indicate that factors other than market share and entry barriers will again receive less weight in highly concentrated markets, or in markets dominated by a leading firm. ${ }^{45}$ While the FTC Statement did not attempt to set any exact quantitative cutoffs corresponding to those in the Guidelines, it also made clear that the weight given to other factors would decrease in direct proportion to the level of concentration in the market. ${ }^{46}$

Thus, the first effect of the Guidelines is to specify a relatively large range of cases in which many of the factors that courts have been considering will be given hittle or no weight. For cases that fall between the two extremes, of course, the enforcement agencies will consider a wider range of factors, making the outcome less certain. This result is only logical; indeed, there would be something fundamentally wrong with any set of guidelines that could not provide greater certainty at the extremes than in the middle. Even in this middle range, however, the Guidelines better facilitate predictability than most judicial opinions because the Guidelines address the relative iniportance to be given to other factors. This is accomplished by clearly delineating the implications of the economic model on which the Guidelines are based.

\section{B. Specifying the Economic Model}

One of the most important contributions of the Guidelines is that they clearly specify the goal of merger enforcement. The Guidelines are based on a very straightforward economic model which holds that, as concentration increases, either single firm market power or oligopolistic cooperation is also likely to mcrease. That is, either a single firm may grow so large that it can unilaterally raise price above the competitive level without very rapidly losing its market share, or if there is no dominant firm, the larger firms in the industry may realize their interdependence and find it easier to collude either tacitly or explicitly. The Guidelines were designed to prevent these dangers from

43. The specific threshold levels are discussed in depth elsewhere in this volume: Kauper, The 1982 Horizontal Merger Guidelines: Of Collusion, Efficiency, and Failure, 71 CALIF. L. REv. 497 (1983).

44. Guidelines $\S \operatorname{III}(\mathrm{A})(\mathrm{I})(\mathrm{a}), 47 \mathrm{Fed}$. Reg. at $28,497,71$ CALIF. L. REv. at 656 . The Herfindahl-Hirschman Index is discussed in depth elsewhere in this volume: Calkins, The New Merger Guidelines and the Herfindahl-Hirschman Index, 71 CALIF. L. REV. 402 (1983).

45. Guidelines at $\S \operatorname{III}(\mathrm{A})(1)(\mathrm{c}), \operatorname{III}(\mathrm{A})(2), 47 \mathrm{Fed}$. Reg. at $28,497-98,71$ CALIF. L. REv. at 656-57.

46. FTC Statement, supra note $1, \S \mathrm{III}(\mathrm{A})(1)$, TRADE REg. REP. (CCH) No. 546, at 78. 
occurring. ${ }^{47}$

Many commentators argue that this approach is too narrow, and that there are other goals of the merger laws that should be considered. ${ }^{48}$ This debate cannot be resolved here. Although social concerns are often cited in discussions of merger pohicy, they are difficult to translate directly into enforcement criteria. Moreover, in most cases, prevention of economically objectionable mergers will serve the social goals as well. ${ }^{49}$ Objection to the Guidelines based on social concerns would require the merger law to consider an even wider and more diverse set of factors than under the pre-Guidelines case law. On the other hand, from the standpoint of making the law more focused and predictable, the narrower approach has much to recommend it. Not only does the narrower approach make it easier to identify the relevant factors, it also makes it easier to judge their relative importance.

For example, tacit or exphicit collusion is generally beheved to be easier, all else equal, when products are homogenous, when the product is sold to a large number of buyers, and when information about each firm's prices and sales is readily available to competitors. ${ }^{50}$ The Guidelines therefore include these as relevant factors ${ }^{51}$ but they also exclude these factors from consideration im cases in which the concern is that the inerging firm has become so large that it can exercise market power without cooperating with its rivals. ${ }^{52}$ When cooperation is no longer a concern, neither are those factors that would facilitate cooperation.

A similar analysis defines the relationship between barriers to en-

47. See Guidelines $§ 1,47$ Fed. Reg. at 28,494, 71 CALIF. L. REv. at 649-50; FTC Statement, supra note $2, \S$ II, TRADE REG. REP. (CCH) No. 546, at 74.

48. For some recent discussion, see 1 P. AREEDA \& D. TURnER, ANTITrust LAW If 103-113 (1978); Elzinga, The Goals of Antitrust: Other than Competition and Efficiency, What Else Counts?, 125 U. PA. L. Rev. 1191, 1194-203, 1213 (1977); Pitofsky, The Political Content of Antitrust, 127 U. PA. L. REV. 1051, 1051-58 (1979); Schwartz, "Justice" and Other Non-Economic Goals of Antitrust, 127 U. PA. L. REv. 1076, 1086 (1979); Sullivan, Economics and More Humanistic Disciplines: What Are the Sources of Wisdom for Antitrust?, 125 U. PA. L. REv. 1214, 1220 (1977). A research project recently completed under the auspices of The Conference Board and Columbia University's Center for Law and Economic Studies addressed the issue of whether there is a positive relationship between corporate size and undesirable social and pohtical consequences. The papers that resulted from the research found hitle empirical support to this effect. These papers will be published by the Coluunbia University Press in late 1983 or early 1984. See Research Finds Corporate Bigness Produces Few Detrimental Effects, 43 ANTITRUST \& TRADE REg. REP. (BNA) 972-76 (Nov. 25, 1982).

49. Thus, the FTC Statement noted that the antimerger laws "also reflected Congress' concern about the overall social and pohtical ramifications of economic concentration . . . ." However, the FTC did not attempt to build factors refiecting these ramifications into our enforcement criteria. FTC Stateınent, supra note 2, § II, TRADE REG. REP. (CCH) No. 546, at 74.

50. See Hay \& Kelley, An Empirical Survey of Price Fixing Conspiracies, 17 J.L. \& EcoN. 13, 14-15 (1974).

51. Guidelines $\S$ III(C), 47 Fed. Reg. at 28,498, 71 CALIF. L. REV. at 657-58.

52. Guidelines $\S \mathrm{III}(\mathrm{A})(2), 47$ Fed. Reg. at 28,497-98, 71 CALIF. L. REV. at 657. 
try and the factors that facilitate collusion. The economic model on which the Guidelines are based imphes that collusion is only likely to be effective in markets that are protected by some form of barrier to entry. Thus, it is only in markets where barriers to entry are significant that the factors facilitating collusion take on any relevance at all. If there are no barriers to entry, collusion is unlikely to be effective no inatter how inany facilitating factors are present, and therefore there is less need to take such factors into account. This is precisely the approach suggested by the Guidelines. ${ }^{53}$

These may seem like obvious points, but making them obvious is important for the predictability of any legal standard. The relevant distinction here is between a model and a laundry list. A mere histing of all the factors that imght be relevant-as is often found in judicial opinions-suggests that each of the factors must be imvestigated in every case. It suggests nothing about the weight to be given each factor. Suclı a list is therefore of little help in making a decision when, as is often the case, half the factors cut in one direction and lialf in the other. Only a model that explains why each factor is relevant can explain low the factors are likely to be related to one another in any particular inerger.

This point is perliaps best illustrated witl respect to market definition. Merely listing the relevant factors-as the Supreme Court did in Brown Shoe, ${ }^{54}$ for example-gives no indication about what a court will do wlien, as is usually true, not all of the factors are present. ${ }^{55}$ The Guidelines, by contrast, begm by making clear that the fundamental reason for determining market definition is to identify those firms that, if they collude or merge into a single dominant firm, could raise prices witlout losing most of their customers. ${ }^{56}$ This automatically implies that the various factors histed by the court will be relevant only insofar as they contribute to an informed prediction about how buyers would

53. See FTC Statement, supra note 2 , § III, TRADE REG. ReP. (CCH) No. 546, at 77 ("The issue of entry barriers is perhaps the most important qualitative factor . . . ."); $c f$. Guidelines § III(C), 47 Fed. Reg. at 28,498-99, 7I CALIF. L. Rev. at 657-60.

54. In Brown Shoe, 370 U.S. at 325 , the Court states:

The boundaries of [a relevant submarket] inay be determined by examining such practical indicia as imdustry or public recognition of the subinarket as a separate economic entity, the product's peculiar characteristics and uses, unique production facilities, distimct customers, distinct prices, sensitivity to price changes, and specialized vendors.

55. Moreover, the Court's subinarket analysis further complicated this process because inarket shares could apparently be calculated on the basis of any single subinarket or any coinbination of submarkets. Rome Cable, 377 U.S. at 276-77. Similarly, in Continental Can, 378 U.S. at 45758 , the Court indicated that substitute products inade by the two merging firms could be defined as a single submarket while excluding other equally close substitutes-a position explicitly rejected by the new Guidelines. See Guidelines $\S \mathrm{II}(\mathrm{A})$ n.12, 47 Fed. Reg. at 28,495 n.12, 71 CALIF. L. REV. at 651 n.12.

56. Guidelines § II(A)-(B), 47 Fed. Reg. at 28,494-95, 71 CALIF. L. Rev. at 650-53. 
respond to a price increase. Industry or public recognition of a distinct market, for example, might well be probative evidence on this point if there were no contrary evidence. If, lowever, more direct evidence can be obtained, such as evidence of past substitution of one product for the other or statistical evidence of similarities in price movements, the weight attached to the public recognition factor would decline.

Obviously, this sort of analysis will nọt elimmate all uncertainty about inarket definition under the Guidelines. Buyer responses are difficult to predict even under the best of conditions, and reasonable people, and reasonable judges, will frequently disagree. There is likely to be less uncertainty about this ultimate issue, however, than there would be if each of the relevant factors were given independent significance, as reasonable people are even more likely to disagree over each of the factors taken individually. In this sense, the Guidelines can only be viewed as an improvenient over the existing inarket-definition process.

\section{Limiting the Admissible Factors}

Finally, it slould be pointed out that the Guidelines do exclude fron consideration a nuniber of factors that inight occasionally have theoretical relevance. Perlaaps the inost important example concerns mergers that allegedly increase the efficiency of the merged firm. Citing the difficulties involved in measuring suclu efficiencies, anong other reasons, the Guidelines indicate that potential efficiencies generally would not be considered a relevant factor, except perhaps in the most extreme cases. ${ }^{57}$ For similar reasons, the FTC Statement indicated that only certain kinds of efficiencies would be considered as a factor influencing prosecutorial discretion rather than as a legal defense. Even then, such efficiencies would only be considered if the inerging parties could prove with substantial evidence that the efficiencies clearly outweighed any increase in inarket power and could not have been achieved in any other way. ${ }^{58}$

Consideration of other factors is also limited. The existence of increasing or declining demand, which the lower courts have treated in a soinewlat mixed fashion, ${ }^{59}$ is given little independent significance by

57. Guidelines §IV(A), 47 Fed. Reg. at 28,499-500, 71 CALIF. L. Rev. at 660-62. The Guidelines' treatment of the efficiency defense is discussed in more detail by Kauper, supra note 43, at 519-25. See also 4 P. AREedA \& D. TURNeR, supra note 48, 11 949-960 (1980); Fisher \& Lande, Efficiency Considerations in Merger Enforcement, 92 YALE L.J. - (1983) (forthcoming); Muris, The Efficiency Defense Under Section 7 of the Clayton Act, 30 CASE W. Res. L. REv. 381, 416-31 (1980).

58. FTC Statement, supra note 1 , \& IV, TRAdE REg. ReP. (CCH) No. 546, at 81. Clairman Miller of the FTC would have treated efficiencies as a legal defense in merger cases. Id. at n.22.

59. See supra note 37. 
the Guidelines. ${ }^{60}$ Regarding the timing of entry, the Guidelines simply decline to consider any entry that would take longer than two years to materialize. ${ }^{61}$ Many of these exclusions may not be of great practical importance when taken individually; however, they demonstrate that the Guidelines are not an attempt to turn every inerger case into a coinpletely open-ended imquiry into all relevant factors. What they show is that, $\mathrm{m}$ striking the balance between finely tuned decisions and predictable rules, the Guidelines have frequently come down on the side of predictability.

Of course, even if the Guidelines are more definite and predictable than the current case law, this does not necessarily imply that the Guidelines have achieved the optimal level of specificity. ${ }^{62}$ Still, there is at least a rough sort of rationality to the structure of the Guidelines. The Guidelines assume that market concentration is relatively easy to measure ${ }^{63}$ and is probably the best predictor of coinpetitive effects of horizontal inergers; 64 therefore, the Guidelines accord the most weight to concentration. ${ }^{65}$ Furthermore, the initial screening to identify unconcentrated or highly concentrated markets, where other factors will

60. The only reference to this factor is a brief one in the FTC Statement, supra note $1, \S \mathrm{III}$, TRADE REg. REP. (CCH) No. 546, at 77 ("Market power also may be harder to exercise or less likely to endure im the face of . . . significant upward shifts im demand."). Even there, the context makes it clear that increasing demand is relevant only as one piece of evidence bearing on the likelihood of long-term collusion or market power, and that the weight given this factor will therefore depend on what other evidence (e.g., evidence of barriers to entry) is available on this point.

61. Guidelines \& III(B), 47 Fed. Reg. at 28,498, 71 CAL1F. L. REV. at 657.

62. A claim of optimal specificity is much more difficult to make. The theory involved in attaining optinal specifity is relatively straightforward, because each additional factor introduced into the inquiry carries with it some effect on the likelihood of condemning or deterring an innocuous inerger (a "Type I error") and soine effect on the likelihood of not preventing an anticompetitive merger that ought to be condeinned (a "Type II error"). In theory, the antitrust enforcement agencies should continue to expand the list of factors to be considered until the extent to which the next factor would improve decisionmaking (i.e., their power in preventing Type I and Type II errors) is equal to the cost of gathering evidence on that factor. For a general treatment of these issues, see H. RAIFFA, Decision ANALysis: Lectures ON ChOICES UNDER UNCERTAINTY (1968). However, these theoretical calculations are very difficult in practice because there is very little evidence as to: 1) the likelihood of either type of error; 2) the amount of harm inflicted by either type of error; and 3 ) the power of any particular factor or criterion in reducing those errors.

63. This, of course, assumes that the relevant market is readily definable. Once the relevant market is defined, the Guidelines suggest that the inarket will generally include the total sales or capacity of all firms in the inarket. Guidelines $\$$ II(D), 47 Fed. Reg. at 28,496, 71 CALIF. L. REv. at 654 . This is a relatively straightforward method for determining the size of the market, and concentration in the industry.

64. The best evidence of the Guidelines' faith in the predictive accuracy of concentration can be found in the discussion of horizontal mergers. The Guidelines state that for a horizontal merger, concentration will be the first factor to be examined. Guidelines $\$$ III, 47 Fed. Reg. at 28,496, 71 CALIF. L. REV. at 655. Moreover, if concentration is low enough, no other factor need be examined. Id. , 47 Fed. Reg. at 28,496-97, 71 CALIF. L. REv. at 655.

65. See supra text accompanying notes $43-46$. 
be less important, is done solely on the basis of market concentration. ${ }^{66}$ Entry barriers are also an extremely important predictive factor, ${ }^{67}$ but are, unfortunately, often difficult to measure. ${ }^{68}$ They are therefore incorporated im a very rough sort of way, and only after the initial screening on the basis of inarket concentration. ${ }^{69}$ Structural factors that might facilitate collusion, even if easier to observe, are of less predictive value and therefore are given less importance in most cases. ${ }^{70}$ Finally, conduct variables - such as profit rates, or the apparent vigor of price competition-are usually difficult to observe and of uncertain predictive value. ${ }^{71}$ Therefore, such conduct variables are accorded relatively little weight, except $\mathrm{m}$ those very close cases where the issue is still in doubt after considering market concentration and entry barriers. ${ }^{72}$

\section{III}

\section{Applications to Other Areas}

The ready adoption of guidelines for merger analysis may im part be due to the fact that merger law is an explicit attempt to forecast future events. There is, of course, no way that future events can ever be forecasted with certamty; ${ }^{73}$ however, by focusing their mquiry on factors that possess predictive value, antitrust enforcement agencies will tend to maximize the accuracy of their forecasts. However, it nay be possible to implement a structural inquiry, similar to that of the Guidelines, in other areas of antitrust laws.

66. See supra text accompanying notes $44-47$.

67. R. Posner, Antitrust Law 57-59 (1976); F. Scherer, Industrial Market StructUre and Economic Performance 236 (2d ed. 1980). See also Guidelimes $\S \mathrm{III}(\mathrm{C}), 47$ Fed. Reg. at 28,496-99, 71 CALIF. L. REv. at 655-60; FTC Statement, supra note 1, \& III, TRADE REG. REP. (CCH) No. 546, at 77 ("The issue of entry barriers is perhaps the most important qualitative factor.").

68. Cf. L. Sullivan, HANDBOoK OF THE LAW OF ANTITRUST § 205, at 640-42 (1977) (positing that objective evidence of potential entry is indeterminate, making use of subjective evidence necessary).

69. Thus, the Guidelines $\S \mathrm{III}(\mathrm{B}), 47 \mathrm{Fed}$. Reg. at 28,498, 71 CALIF. L. Rev. at 657, draws only a single distinction, between markets where a $5 \%$ price increase will induce entry within two years and markets where entry will not occur or will take longer. Guidelines $\S 111(\mathrm{~B}), 47 \mathrm{Fed}$. Reg. at $28,498,71$ CALIF. L. Rev. at 657 . No attempt is made to distinguish gradations in the likelihood of entry on either side of that line.

70. Guidelines \& III(C), $47 \mathrm{Fed}$. Reg. at 28,498-99, 71 CaLIF. L. Rev. at 657-60.

71. See 2 P. AREEDA \& D. TURNER, supra note 48, 11 510-512c (1978). For a discussion of the diffieulties of determining and using profit rate data, see Harris \& Jorde, Market Definition in the Merger Guidelines: Implications for Antitrust Enforcement, 71 CALIF. L. REv. 464, 482-84 (1983).

72. Guidelines \& III(C), 47 Fed. Reg. at 28,498-99, 71 CaLIF. L. Rev. at 657-60.

73. The role of postacquisition evidence in challenges to inergers that have already been consummated is a separate question - and an increasingly infrequent one, due to the advance notice requirements of the Hart-Scott-Rodino Antitrust Improvement Act of 1976, Pub. L. No. 94435, 90 Stat. 1383-that is beyond the scope of this Article. 
In many areas of antitrust law there is a similar difficulty in ascertaining the competitive effects of a challenged practice, even after the practice has ceased. Predatory pricing cases, for example, raise notoriously difficult problems of distimguishing innocent, competitive price cuts from anticompetitive, predatory ones. ${ }^{74}$ Vertical distributional restraints, now that all except resale price maintenance inust be judged under a rule of reason, pose similarly difficult problems. ${ }^{75}$ Tying arrangements, though nominally illegal per se, are increasmgly permitted as courts attempt to balance asserted business justifications against any anticompetitive effects. ${ }^{76}$ The same is now true of some kinds of horizontal agreements, when they do not appear to constitute outright price fixing and may have some business justifications. ${ }^{77}$

A common difficulty in all these areas is that conduct tests, or tests that attempt to measure directly the costs and benefits of the challenged restraint, are extreinely complex and unrehable. This, of course, does not mean that conduct tests should be abandoned, for there is no easy way to avoid some sort of scrutiny of the challenged practice. ${ }^{78}$ It might, however, be possible to limit the importance of such tests, and the resultimg uncertainty for executives, by invoking them only in cases where more easily observable structural characteristics make the undesirable effects reasonably likely. In other words, it might be possible to address these sorts of problems through the same sort of structured inquiry employed by the Guidelines.

Indeed, such an approach has already been suggested in the area of predatory pricing. ${ }^{79}$ Professors Joskow and Klevorick have proposed a two-tier inquiry, the first tier of which would ask whether the structural characteristics of the market, primarily market shares and barriers to entry, make predation likely to be a profitable strategy. If the answer were "No," the case would be dismissed without any reference to any other factors or tests. Only if the answer were "Yes" would the courts or the enforceinent agencies attempt to apply a cost-based con-

74. For a recent review of that literature, see Joskow \& Klevorick, $A$ Framework for Analyzing Predatory Pricing Policy, 89 Yale L.J. 213, 213-14 n.1 (1979). See also FTC, Strategy, PREDation ANd ANTITRUSt ANalysis (S. Salop ed. 1981).

75. Continęntal T.V., Inc. v. GTE Sylvania Inc., 433 U.S. 36, 57-59 (1977)

76. See Principe v. McDonald's Corp., 631 F.2d 303, 307-11 (4th Cir. 1980), cert. denied, 451 U.S. 970 (1981); State v. Lawn King, Inc., 84 N.J. 179, 208-10, 417 A.2d 1025, 1040-42 (1980). Indeed, over the last five years inore than $80 \%$ of the tying cases to reach a decision on the inerits were decided in favor of the defendant. See Craswell, Tying Requirements in Competitive Markets: The Consumer Protection Issues, 62 B.U.L. REv. 661, 698-99 (1982).

77. See Broadcast Music, Inc. v. CBS, 441 U.S. 1, 7-16 (1979).

78. Conduct tests could, however, be abandoned if an extreine rule of per se legality were adopted. For some recent discussions advocating this approacl, see Easterbrook, Predatory Strategies and Counterstrategies, 48 U. CHI. L. Rev. 263, 333-37 (1981); Posner, The Next Step in the Antitrust Treatment of Restricted Distribution: Per Se Legality, 48 U. CHI. L. Rev. 6, 22-26 (1981).

79. Joskow \& Klevorick, supra note 74, at 242-62. 
duct standard to determine whether the defendant's pricing was predatory.

The FTC recently moved in a similar direction with respect to territorial restrictions and exclusive dealing requirements in Beltone Electronics Corp. ${ }^{80}$ After noting that its primary concern was the effect upon horizontal interbrand competition, the Commission reviewed the structural factors that would make such an effect more or less hikely. Of particular importance was the fact that the market was relatively unconcentrated (with the respondent's inarket share decliming), and that barriers to entry were low (as evidenced by the success of several recent entrants). ${ }^{81}$ Structural factors bearing on the likelihood of explicit or tacit collusion, such as product heterogeneity, were also considered. ${ }^{82}$ On the basis of these easily observable structural characteristics, the likelihood of undesirable interbrand effects appeared to be so low that there was hittle need to undertake the difficult task of assessing the justifications for the restraints. ${ }^{83}$

\section{CONCLUSION}

The new Guidelines help improve the specificity and predictability of modern merger law. By structuring the inquiry to make it clear when certain factors will be relevant and when they will not, the Guidelines should reduce the uncertainty to busmessmen as well as improve the selectivity of the enforcement agencies' challenges.

The desirability of certainty and predictability is not limited to merger law. If anything, predictability may have even inore importance in areas such as predatory pricing, where there is an even greater concern that the law not unintentionally chill desirable price cuts. The next task, therefore -in addition to carefully applying the Guidelines in future merger cases-is to determine whether a similar structure and focus can be brought to the inquiry in other areas of antitrust law.

80. No. 8928 (FTC July 6, 1982).

81. Id., slip op. at 41.

82. Id. slip op. at 42-43.

83. In fact, Federal Trade Commissioner Bailey was willing to dispense totally with assessing alleged justifications once analysis showed that undesirable interbrand effects were extremely unlikely. Id. (Bailey, Comm'r, concurring). 